\title{
Agricultural innovation in East Otago: helping to shape New Zealand's farming industry
}

\author{
D.R. STEVENS and K.A. COUSINS \\ AgResearch Invermay, Private Bag 50034, Mosgiel \\ david.stevens@agresearch.co.nz
}

\begin{abstract}
The East Otago region has been at the forefront of agricultural advancement in New Zealand with key people leading the way in creating a culture of innovation. Rural technology developments are traced back from the emerging new biotechnology industries, through animal genetics research, improvements in hill country and pasture production, soil and fertiliser research, the introduction of deer farming and sheep breeding, to the frozen meat shipments, agricultural organisation restructuring and land reforms of the early settlers.
\end{abstract}

Keywords: deer, genetics, grazing management, history, innovation, sheep, soil classification, soil fertility, technology

\section{Introduction}

All New Zealanders will be able to identify with people in their region who have utilised their creative and entrepreneurial talents for the betterment of farming and economic growth. But why is Otago, near the bottom of the country and a long way from world research and business networks, consistently producing high calibre agricultural innovators? Toni Myers, in an article for 'Management' (Myers 2005) examined this question in relation to New Zealand as a whole. Critical factors were seen to be our record of good science and support from government programmes and incentives. New Zealand's isolation is also thought to encourage creativity to solve unique problems.

'Innovation is not a business process. It's an entire way of life, for individuals and society' (Oram 2001). This culture of innovation was established early in Otago's history because of the new challenges faced by the European settlers. Despite the region's isolation, farmers, politicians, business entrepreneurs and scientists have collaborated with ideas, research and money to progress economic growth based on agricultural productivity. This paper uses key periods of change in East Otago's farming history to review progress in agricultural technology. We begin in the recent past and work back, highlighting key innovators who have had the vision and entrepreneurial skills to make a difference. To quote Sir Isaac Newton 'If I have seen further it is by standing on the shoulders of giants' (Bragg 1998).

\section{Advancing the Future of Agricultural Biotechnology}

In 2002 the New Zealand Government introduced the Growth and Innovation Framework (NZGE 2002) which identified innovation as the strategy to take the economy of New Zealand forward. Biotechnology was one of the key areas to be targeted. Long before this, Otago business entrepreneur, Howard Patterson had already recognised that the biotechnology industry would be the way of the future, when he established Zenith Technologies Ltd in 1987, and later, the venture capital company, Quest VC. Patterson was raised on the family farm near Waikouaiti and educated at the University of Otago. In the early 1990s he focused his entrepreneurial skills on agriculture and formed Tasman Agriculture Ltd, pioneering the expansion of dairy farming in the South Island and establishing New Zealand Deer Farms Ltd. Patterson captured benefits for New Zealand agriculture from biotechnology by turning away from traditional drug development to new products such as functional foods (Macfie 2003).

Several other initiatives have emerged from research institutions in Otago. Companies investing in biotechnology R \& D and commercialisation have formed a network called bioSouth which extends to approximately 60 companies, of which 26 are related to agriculture. A sample of these includes: Global Technologies (NZ) Ltd (DNA links to meat quality parameters and food traceability); Otago Innovation Ltd (technologies to trace products throughout the world); Ovita (commercialising discoveries in the sheep genome); Scott Automation (robotic systems for automated animal carcass processing); Abacus Biotech Ltd (scientific consultancy and new venture agricultural business development).

Products are being developed to add value to agricultural production. Zenith Technology Corporation Ltd has commercialised products such as ImmunoZen ${ }^{\mathrm{TM}}$, a colostrum health supplement, and BOTRYZen $\AA$, a botrytis preventative. Other products such as easiTrace ${ }^{\mathrm{TM}}$ are being made available to ensure meat product authenticity and safety in international markets. A2 Milk $^{\mathrm{TM}}$ is also an example of the differentiation of agricultural products with added value.

Professor Diana Hill, chief executive of Global Technologies (NZ) Ltd, founded the joint AgResearch/ 
University of Otago Molecular Biology Unit in the mid 1980s. In 1986, she initiated New Zealand's first major agri-biotechnology project which constructed sheep (Maddox et al. 2001) and deer (Slate et al. 2002) gene maps, and commercialised DNA based animal diagnostic tools (Galloway et al. 1999). Her awareness of the possibilities and problems of collaboration between science and business led to the establishment of Global Technologies (NZ) Ltd. This was a joint commercial venture to provide a buffer between the two diverse cultural camps, scientists and business (Burns 2004).

Identification of specific genes and gene markers has also accompanied the establishment of the sheep gene map. Recent advances include the location of the Boorola (Montgomery et al. 2001) and Inverdale (Davis et al. 1995) genes and the identification of muscling genes in sheep (Hagen et al. 2005). Current research aims to identify the physiological processes and genes involved in lamb survival (Kerslake et al. 2005) and internal parasite resistance (Diez et al. 2002).

\section{Developing the Genetics and Technologies for New Industries}

This era of capturing biotechnology developments was preceded by significant expansion and redirection of research. As Invermay Director from1978 to 1986, Jock Allison established Invermay at its new site and research began to focus on the agricultural biotechnology industries. Allison's fight for 'top facilities for top people to do their best' (J. Allison, pers. comm.) inspired excellence from the scientists at Invermay and reinforced Invermay's reputation as a world renowned research centre.

\section{Sheep}

Quantitative sheep genetics and gene discovery were emphasised under Allison's leadership. George Davis returned from South Korea to Invermay and took up the challenge to identify 'outliers' that produced outstanding reproductive performance in the sheep population (Davis 1994). The foundation was built for the discovery of the Inverdale gene on the $\mathrm{X}$ chromosome, and the final genetic sequencing for accurate identification (Davis et al. 1991; Davis et al. 1995; McNatty et al. 2001). In 1987 'new' exotic sheep breeds, the Finn, Texel and Oxford Down were introduced with the aim of producing as many progeny as possible by their release date in 1990 (Shackell 1999). After leaving Invermay, Jock Allison continued his involvement in sheep genetics by importing East Friesian sheep for their reproduction and milk producing characteristics (Allison 1995). The genes from these breeds are now embedded in sheep flocks, improving the profitability of the New Zealand sheep industry.

Currently used standards for livestock feeding requirements (Nicol 1987) were also finalised during this period with a significant contribution by Peter Fennessy for sheep and deer (Fennessy \& Milligan 1987; Nicol 1987).

The development of two commercial products aided the fight against internal parasites in sheep and cattle (Sanders et al. 2004). WormFECTM, a faecal egg counting technique for evaluating parasite resistance in sheep, led by John McEwan (McEwan 1994), and FECPak International Ltd, on-farm diagnosis of internal parasite infection, led by Greg Mirams (Wallace 2004).

Pregnancy scanning in sheep was commercialised when Rowan Farmer set up Stockscan in 1991. The aim was primarily to scan sheep for eye muscle area but Farmer's experience with quarantined sheep at Invermay gave him an insight into the benefits of pregnancy scanning for managing a sheep flock. An initial 10,000 ewes were scanned for dry ewes in 1991, growing to 50,000 in 1992 and 100,000 the following year. Since then the practice has expanded to include the identification of twins and triplets and has revolutionised the reproductive management of sheep throughout New Zealand (Farmer \& Davis 1999).

\section{Deer}

Returning from $\mathrm{PhD}$ study at Cornell University, Ken Drew was intrigued by the majestic red deer and initiated a deer research programme in 1973 using borrowed animals (Drew 1994). Research outcomes soon established Invermay's reputation as a world leader in farmed red deer research (Fennessy \& Drew 1985). This formed the basis of an industry that has grown to approximately 4000 farms, now projected to produce approximately $25,000 \mathrm{t}$ of venison and $240 \mathrm{t}$ of velvet (dried equivalent) in 2006 (DINZ 2006). Research alone does not ensure the success of an industry. Close ties were formed with entrepreneurs such as Sir Tim Wallis, facilitating the exchange of ideas and knowledge. The most recent information on deer nutrition and management (Casey 2003) reflects the contribution of Invermay to understanding the biology of, and farming practices for deer.

\section{Developing our Hill Country}

Preceding the genetics and deer industry developments, a period of applied research led to significant advances in hill country development. The need for regional research centres was identified during the 1930s as a result of outbreaks of facial eczema and 'bush sickness' or cobalt deficiency (Nightingale 1992). These diseases were specific to various regions and could not be studied by a central research site. 
Invermay Research Station was established in 1949 under the leadership of George Holmes (Shackell 1999). The need for a research station in the south was taken to the Government by a deputation of Otago and Southland farmers in 1937, but the outbreak of World War 2 delayed progress. Renewed efforts after the war by farmers were boosted by the Mayor of Mosgiel, Bill Hartstonge, and land set aside for returned servicemen was allocated to the Department of Agriculture (Lewis 1985). The close involvement of the farmers continues to be a critical factor in the influence of Invermay.

\section{Pasture production and improvement}

The appointment of Nelson Cullen, Invermay's second director, provided impetus for improvement in hill country farming and pasture production. Cultivation methods and seeding rates still in use today were experimented with during the 1950s (Duff 1958). Increases in productivity and profitability followed from Murray Stockdill's research into earthworms in pasture (Stockdill 1982) and Humphrey Jagger's promotion of rotational grazing to replace set stocking systems for sheep (Jagger 1977). The basic principles of hill and high country pasture production were researched in depth (Cossens 1990) and methods for hill and high country development were eventually published in 'The Guide to Tussock Grassland Farming' (Floate 1992).

The first experiments using aircraft for agricultural purposes were carried out at Tara Hills, Invermay's high country research station (Boswell 1999). Robin Scott, leader of this programme, became a national expert in aerial oversowing and pesticide application (Andrews 1999).

Rhizobia use and seed pelleting for over-sowing was another significant area of research at Invermay. Bill Lowther first studied the requirements of inoculation in Australia (Lowther \& Loneragan 1968) and then in the New Zealand high country (Adams \& Lowther 1970). Research into inoculation and seed coating (Lowther 1975) led to collaborations between Invermay and private industry to establish New Zealand's seed coating processes (Lowther \& Bonish 1980). Later developments in the inoculation (Pryor et al. 1998) and establishment (Lowther et al. 1998) of Caucasian clover and the interspecific hybrids with white clover (Widdup et al. 2003) were also researched at Invermay.

\section{Understanding our soils}

Determining the role of molybdenum in hill country pasture production was an important first step in understanding trace element requirements (Cullen 1954). Invermay scientists were also involved in researching and promoting practical knowledge of soil fertiliser requirements and soil fertility processes. Ian
Cornforth and Alan Sinclair published 'Fertiliser Recommendations for Pastures and Crops in New Zealand' (Cornforth \& Sinclair 1982). This was an incorporation of a series of models of nutrient cycles (Boswell 1999) which evolved into the Overseer ${ }^{\circledR}$ nutrient budgeting and fertiliser recommendation software (Wheeler et al. 2003).

The classification of soils is a key step in understanding their use and limitations. Mike Leamy, of the New Zealand Soil Bureau, played an integral part in establishing both the national (Leamy et al. 1983; Deckers et al. 2002) and international soil classification systems (Deckers et al. 2002) that we continue to rely on today when recommending fertiliser applications and land usage (Hewitt 1992).

The classification of both soil and climatic resources, and its application to crop and pasture production (Cossens 1987; McIntosh et al. 1989; Hutchinson \& McIntosh 2000) added another important tool in the farmers fight against stress. Without this research, the attributes of Central Otago Pinot Noir for fighting heart disease and cancer may not have been available to New Zealand farmers.

\section{Setting the Scene for New Zealand's Farming Future}

These improvements in pastoral production were made possible by early innovators in Otago who set the scene for the expansion of farming in New Zealand during the 1880 s.

Sir John McKenzie (1839-1901), as farmer and political reformer, initiated the division of large farms into smaller economic units. At the age of 5 , he had witnessed the sad result of landlordism in Scotland - the crofters and tenant farmers of Glencalvie huddled together in a graveyard after being evicted from their land. This memory of the highland clearances was a prime motivation for overturning the land monopoly existing in his new adopted country. As Minister of Lands in Richard Seddon's Liberal Cabinet (18911900) McKenzie continued the work of another Otago politician and businessman, Donald Reid, and finally achieved the introduction of laws that shifted the power from the runholders to the settlers (Brooking 1996). These included a graduated land tax, the restriction of building large estates through the purchase of 'waste lands' and the lease-in-perpetuity tenure or 999-year lease (Evans 1969). McKenzie's passionate advocation of closer settlement resulted in 1.3 million acres of land being opened up to approximately 7000 farming families.

Informal and non-political Agricultural and Pastoral Associations had been the only means by which farmers shared information during the mid-late 1800 s. 
McKenzie recognized the need for dissemination of the latest technical research and helped establish the Department of Agriculture in 1892, merging the Stock Department and the Agricultural Branch of the Land Survey Department. Veterinarians, skilled in the latest microbiology technology, and dairy instructors were employed to assist the farming community (Nightingale 1992).

\section{Development of refrigerated shipping}

In 1882, the first shipment of refrigerated meat and dairy products left from Port Chalmers on the S.S. Dunedin for London. Historically, Thomas Brydone (18371904 ) is credited with initiating this successful export venture. It was in fact William Davidson (1846-1924), at the time General Manager of the New Zealand and Australian Land Company and based in Scotland, who realised the potential of the new refrigeration technology and conceived the idea. Brydone, under Davidson's direction, supervised the selection of stock for the refrigerated shipment and established the slaughtering facilities at Totara in North Otago (Hewland 1958).

The benefits of a supply of frozen meat from the 'colonies' was immediately praised as an opportunity for Britain to source her needs from 'kith and kin' rather than 'those who one day may be her enemies' as quoted from a letter to the Editor of the Times (London) from the Agent-General of New Zealand (Hepburn 1982). A secure trade and the availability of artificial fertilisers from by-products of the freezing works (Evans 1969) enabled an increase in production.

\section{Early farming developments}

Davidson was a man of vision, a skilful, enterprising businessman with a practical background in pastoral farming. He travelled widely and consulted with experts in the dairy industry in Denmark and Canada. As a result Danish cheese making skills were brought back to New Zealand. He was aware of James Little's pioneering work in establishing the Corriedale sheep breed and encouraged the development of a stud flock at the Levels (Palmer 2006).

Other innovations followed for agricultural machinery. The Dunedin company, Reid and Gray, produced ploughs, modified for New Zealand conditions, that became legendary. The Hayes fence strainer was also an innovation that improved the efficiency of the farmer (Campbell 2003). The Milburn Lime and Cement Company established the first agricultural lime industry in New Zealand.

\section{Failures}

Not all innovations were successful. Attempts to induce rain in North Otago in 1892 were at first reported as having a promising outcome. 'We might note that the first explosion .... resulted in the wind ceasing and rain falling during the night' (Hepburn 1982). Further evidence of success at any later date cannot be found.

More recently, in the pursuit of treatments for grass grub, Ken Stewart decided that heavy rolling could be the answer. The prototype roller never proceeded beyond this stage as its shape and weight were well beyond the power of most tractors and the patience of most farmers.

Deer industry research has also had its failures. An attempt to change the calving date by introducing the Père David's deer eventually produced some fertile offspring. The project soon declined due to the incompatibility of short day and long day responsive genes and the susceptibility of the Père David's deer to disease. However, it did provide a valuable tool in mapping the genome of the red deer (Slate et al. 2002).

\section{Conclusions}

The innovative culture began in the farming settlements as immigrants fought for equitable land settlement policies. They quickly adopted new opportunities such as refrigeration that helped secure the economic future of farming. New supporting structures such as the Department of Agriculture were established. These changes resulted in rapid expansion of New Zealand's farming wealth and its continued importance in today's economy.

The lobbying of farmers established the Invermay Research Station, a key development in innovation. Agricultural development was aided by research which established techniques and knowledge for national hill country improvement, land use and fertiliser recommendations. Understanding deer nutrition and management helped establish a successful New Zealand deer industry. Genetic research, gene discovery and animal physiology research have helped create the foundation for an emerging biotechnology industry.

We are fortunate to have benefited from the passion, creativity, energy and commitment of our innovative farmers, entrepreneurs, politicians, and research leaders. We cannot 'stand on the shoulders of giants' (Bragg 1998) and see clearly into the future. We can, however, reflect on our culture of innovation, apparent since early agricultural settlement, and have confidence that New Zealand will profit from future opportunities identified in East Otago.

\section{ACKNOWLEDGEMENTS}

The authors would like to acknowledge all of the other innovators and researchers from the Otago region that may not have been mentioned. It is our regret that we do not have the space to praise these keen agricultural 
advocates, but we have chosen our set of key innovators to express the spirit of the province.

\section{REFERENCES}

Adams, A.F.R.; Lowther, W.L. 1970. Lime, inoculation, and seed coating in the establishment of oversown clovers. New Zealand Journal of Agricultural Research 13: 242-251.

Allison, A.J. 1995. Importing a sheep which offers more - the East Friesian. Proceedings of the New Zealand Society of Animal Production 55: 321-323.

Andrews, R. 1999. Aerial topdressing research at Invermay. pp. 71-72. In: Data and legends. Ed. Shackell, G. H. AgResearch Invermay, Mosgiel, New Zealand.

Boswell, C.C. 1999. The legacy of 50 years of farming and research at Invermay - a look at pasture and soil. pp. 72-79. In: Data and legends. Ed. Shackell, G. H. AgResearch Invermay, Mosgiel, New Zealand.

Bragg, M. 1998. On giants' shoulders. Hodder and Stoughton, London. 365 pp.

Brooking, T. 1996. Lands for the people? University of Otago Press, Dunedin, New Zealand. 363 pp.

Burns, D. 2004. Small and large company partnerships. Bright 4: 9-12.

Campbell, G. 2003. Ernest Hayes: engineer extraordinaire. New Zealand Memories 40: 4-1.

Casey, M.J. (Ed.). 2003. Nutrition and management of deer on grazing systems. Grassland Research and Practice Series 9. 126 pp.

Cornforth, I.S.; Sinclair, A.G. 1982. Fertiliser and lime recommendations for pastures and crops in New Zealand. New Zealand Ministry of Agriculture and Fisheries, Wellington. 66 pp.

Cossens, G.C. 1990. Pasture and lucerne production in Otago and Southland 1950 to 1987. Invermay Technical Report No. 21. Invermay Agricultural Centre, Mosgiel, New Zealand. 31 pp.

Cossens, G.G. 1987. Agriculture and climate in Central Otago. Proceedings of the New Zealand Grassland Association 48: 15-21.

Cullen, N.A. 1954. Molybdenum trials at Invermay. New Zealand Journal of Agriculture 88: 241.

Davis, G. 1994. Encounters with the Inverdale gene (1968-1991). pp. 29-54. In: Lab coats to gumboots. Ed. Davis, G. New Zealand Society of Animal Production, [Wellington].

Davis, G.H.; McEwan, J.C.; Fennessy, P.F.; Dodds, K.G. 1995. Discovery of the Inverdale gene (FecX). Proceedings of the New Zealand Society of Animal Production 55: 289-290.

Davis, G.H.; McEwan, J.C.; Fennessy, P.F.; Dodds, K.G.; Farquhar, P.A. 1991. Evidence for the presence of a major gene influencing ovulation rate on the $\mathrm{X}$ chromosome of sheep. Biology of Reproduction 44: 620-624.

Deckers, J.; Nachtergaele, F.; Spaargaren, O. 2002. Tropical soils in the Classification systems of USDA, FAO and WRB. Accessed 2006: FAO, http:// w w w. fao o r g/a g/a g l/a g $11 /$ w r b/d o c / KAOWDeckerscorr280203.doc

Diez, T.C.; MacDonald, P.A.; Dodds, K.G.; McEwan, J.C.; Crawford, A.M. 2002. A screen of chromosome 1 for QTL affecting nematode resistance in an ovine outcross population. pp. 1-4. In: Proceedings of the 7th World Congress on Genetics Applied to Livestock Production, Montpellier, France, 19-23 August 2002. Session 13.

DINZ 2006. Market Report No. 83. Deer Industry New Zealand.

Drew, K.R. 1994. Deer research - it led the New Zealand industry. pp. 13-28. In: Lab coats to gumboots. Ed. Davis, G. New Zealand Society of Animal Production, [Wellington].

Duff, H.A. 1958. Pasture improvement in low altitude tussock and scrub-land. Proceedings of the New Zealand Grassland Association 20: 70-79.

Evans, B.L. 1969. A history of agricultural production and marketing in New Zealand. Keeling \& Mundy Ltd., Palmerston North, New Zealand. 243 pp.

Farmer, R.J.; Davis, G.H. 1999. Experiences of a pioneer in the commercial sheep pregnancy scanning business. Proceedings of the New Zealand Society of Animal Production 59: 91-92.

Fennessy, P.F.; Drew, K.R. 1985. Biology of deer production. The Royal Society of New Zealand, Wellington. 482 pp.

Fennessy, P.F.; Milligan, K.E. 1987. Grazing management of deer. pp. 111-118. In: Livestock feeding on pasture. Occasional Publication No. 10. Ed. Nicol, A. M. New Zealand Society of Animal Production, Hamilton.

Floate, M.J.S. (Ed.). 1992. Guide to tussock grassland farming. AgResearch Invermay, Mosgiel. 127 pp.

Galloway, S.M.; Cambridge, L.M.; Henry, H.M.; Stijn, T.C.v.; Davis, G.H. 1999. A genetic test to identify carriers of the ovine Inverdale fecundity gene. Proceedings of the New Zealand Society of Animal Production 59: 114-116.

Hagen, I.J.; Zadissa, A.; McEwan, J.C.; Veenvliet, B.A.; Hickey, S.M.; Cullen, N.G.; Morris, C.A.; Wilson, T. 2005. Molecular and bioinformatic strategies for gene discovery for meat traits: a reverse genetics approach. Australian Journal of Experimental Agriculture 45: 801-807.

Hepburn, J. 1982 (August). A century in retrospect. The New Zealand Farmer 103. 240 pp.

Hewitt, A.E. 1992. Soil classification in New Zealand: 
legacy and lessons. Australian Journal of Soil Research 30: 843-854.

Hewland, P.D. 1958. Davidson and Brydone founders of the New Zealand meat export industry. Proceedings of the New Zealand Society of Animal Production 18: 61-76

Hutchinson, G.; McIntosh, P. 2000. A case study of integrated risk assessment mapping in the Southland region of New Zealand. Environmental Toxicology and Chemistry 19: 1143-1147.

Jagger, H.J. 1977. A formula for rotational grazing. New Zealand Agricultural Science 11: 49-50.

Kerslake, J.I.; Everett, H.J.M.; Campbell, A.W. 2005. Lamb survival: a new examination of an old problem. Proceedings of the New Zealand Society of Animal Production 65: 13-18.

Leamy, M.L.; Clayden, B.; Hewitt, A.E. 1983. Soil classification in the New Zealand Soil Bureau. N.Z. Soil News 31: 183-185.

Lewis, K. 1999. The political background. [1985] article reprinted. pp.1-4. In: Data and legends 50 years of Invermay 1949-1999. Ed. Shackell, G.H. AgResearch, Mosgiel, New Zealand.

Lowther, W.L. 1975. Pelleting materials for oversown clover. New Zealand Journal of Experimental Agriculture 3: 121-125.

Lowther, W.L.; Bonish, P.M. 1980. Field evaluation of commercially pelleted clover seed. New Zealand Journal of Experimental Agriculture 8: 249-253.

Lowther, W.L.; Loneragan, J.F. 1968. Calcium and nodulation in subterranean clover (Trifolium subterraneum L.). Plant Physiology 43: 1362-1366.

Lowther, W.L.; Pryor, H.N.; Trainor, K.D. 1998. Strategies to maximise establishment and production of oversown Caucasian clover. Proceedings of the New Zealand Grassland Association 60: 111-114.

Macfie, R. 2003. People or pasture? Unlimited 15-17.

Maddox, J.F.; Davies, K.P.; Crawford, A.M.; Hulme, D.J.; Vaiman, D.; Cribiu, E.P.; Freking, B.A.; Beh, K.J.; Cockett, N.E.; Kang, N.; Riffkin, C.D.; Drinkwater, R.; Moore, S.S.; Dodds, K.G.; Lumsden, J.M.; Stijn, T.C.v.; Phua, S.H.; Adelson, D.L.; Burkin, H.R.; Broom, J.E.; Buitkamp, J.; Cambridge, L.; Cushwa, W.T.; Gerard, E.; Galloway, S.M.; Harrison, B. 2001. An enhanced linkage map of the sheep genome comprising more than 1000 loci. Genome Research 11: 1275-1289.

McEwan, J.C. 1994. WormFEC Breeders' Manual. AgResearch, Invermay.

McIntosh, P.D.; Wilde, R.H.; Webb, T.H. 1989. Soil research applications in horticulture. Annual Journal Royal New Zealand Institute of Horticulture: 28-30.

McNatty, K.P.; Juengel, J.L.; Wilson, T.; Galloway, S.M.; Davis, G.H. 2001. Genetic mutations influencing ovulation rate in sheep. Reproduction Fertility and Development. From elephants to AIDS. Essays in Biology in Honour of Roger V. Short 13: 549-555.

Montgomery, G.W.; Galloway, S.M.; Davis, G.H.; McNatty, K.P. 2001. Genes controlling ovulation rate in sheep. Reproduction (Cambridge) 121: 843-852.

Myers, T. 2005. A rural renaissance: the farm is fertile ground for companies. Management 52: 47-49.

Nicol, A.M. (Ed.). 1987. Feeding livestock on pasture. New Zealand Society of Animal Production, Hamilton. 145 pp.

Nightingale, T. 1992. White collars and gumboots. The Dunmore Press Ltd, Palmerston North. 277 pp.

NZGE 2002. Growing an innovative New Zealand. New Zealand Government Executive - Archive - Rt Hon Helen Clark, [Wellington] Accessed 2006. http:// www.executive.govt.nz/minister/clark/innovate/ innovative.pdf.

Oram, R. 2001. Ministry of innovation: why fresh thinking matters more than ever. Unlimited, Accessed 2006: Unlimited http:/unlimited.co.nz/unlimited.nsf/ default/B30314507359132DCC256A31000C8FA5? Opendocument\&Highlight=2,oram

Palmer, M. 2006. Davidson, William Soltau 1846-1924. Dictionary of New Zealand Biography, updated 7 April 2006 URL: http:/www.dnzb.govt.nz/

Pryor, H.N.; Lowther, W.L.; McIntyre, H.J.; Ronson, C.W. 1998. An inoculant Rhizobium strain for improved establishment and growth of hexaploid Caucasian clover (Trifolium ambiguum). New Zealand Journal of Agricultural Research 41: 179189.

Sanders, C.; Mirams, G.; Familton, A. 2004. The need to improve the current laboratory system. pp. 94-95. In: 30th Conference of the New Zealand Society for Parasitology, October 22-23, 2002, Palmerston North, New Zealand, Sponsor: New Zealand Society for Parasitology.

Shackell, G.H. (Ed.). 1999. Data and legends 50 years of Invermay 1949-1999. AgResearch, Mosgiel. 170 pp.

Slate, J.; Stijn, T.C.v.; Anderson, R.M.; McEwan, K.M.; Maqbool, N.J.; Mathias, H.C.; Bixley, M.J.; Stevens, D.R.; Molenaar, A.J.; Beever, J.E.; Galloway, S.M.; Tate, M.L. 2002. A deer (subfamily Cervinae) genetic linkage map and the evolution of ruminant genomes. Genetics 160: 1587-1597.

Stockdill, S.M.J. 1982. Effects of introduced earthworms on the productivity of New Zealand pastures. Pedobiologia 24: 29-35.

Wallace, N. 2004 (13 Dec). Worm hunter who wriggled out of adversity. Otago Daily Times, p. 18.

Wheeler, D.M.; Ledgard, S.F.; de Klein, C.A.M.; Monaghan, R.M.; Carey, P.L.; McDowell, R.W.; 
Johns, K.L. 2003. OVERSEER nutrient budgets moving towards on-farm resource accounting. Proceedings of the New Zealand Grassland Association 65: 191-194.

Widdup, K.H.; Hussain, S.W.; Williams, W.M.;
Lowther, W.L.; Pryor, H.N.; Sutherland, B.L. 2003. The development and plant characteristics of interspecific hybrids between white and Caucasian clover. Legumes for dryland pastures. Grassland Research and Practice Series No.11: 143-148. 